\title{
TOTAL FACTOR PRODUCTIVITY GROWTH IN UPPER MIDDLE-INCOME BALKAN COUNTRIES FROM 2000-2017, TOTAL ECONOMY AND SECTORAL APPROACH: THE GROWTH ACCOUNTING METHOD
}

The author estimated TFP in the total economy and at sectoral level (agriculture, industry and services) in seven upper middle-income Balkan countries (Albania, Bulgaria, Bosnia and Herzegovina, North Macedonia, Montenegro, Serbia and Romania) from 2000 to 2017, applying the growth accounting approach. This is the first study presenting estimates on TFP on a sectoral level for a selected group of countries, and also the first study presenting estimates on TFP in the total economy for a selected time period. The sample was selected based on income level and geographic criteria. All countries are ex-centrally planned economies. Although several studies presented growth accounting for Central and Eastern European countries for earlier years, very few presented it for Balkan countries, and none for this time frame and using a sectoral approach. In addition, the time frame was split into two subperiods, 2000-2009 and 2010-2017, to gain a better insight into TFP growth in the earlier transitional phase in each country, and including changes which may occur as the country is moving towards a higher income level. Although some countries from the sample, such as Bulgaria and Romania, made transitional progress earlier than others, the economies of all countries from the sample experienced negative trends during the global financial crisis (2007-2009), so the study included that period in the first subperiod. Other than this, the contribution to the literature is the presented methodology for sectoral TFP computation. The research confirmed the importance of sectoral TFP analysis and subperiod analysis, as variations between TFP in the total economy and at sectoral level are significant, but also between two sub periods.

Keywords: total factor productivity (TFP), growth accounting method, upper-middle income economies, Balkans, sectoral approach

JEL Classification: O47, O57

DOI: $10.15611 /$ aoe.2021.1.04

\footnotetext{
* Faculty of Economics, University of Montenegro, Podgorica, Montenegro.
} 


\section{INTRODUCTION}

Total factor productivity (TFP) is the portion of output not explained by the amount of inputs used in production, usually measured by the Solow residual (Solow, 1957). Its level is determined by how efficiently the inputs are utilized in production (Comin, 2010). Total factor productivity is an important determinant of economic fluctuations, economic growth and cross-country per capita income differences, which has been confirmed by many empirical studies. Baier, Dwyer and Tamura (2006), using a sample of 145 countries and data for more than a hundred years for 23 countries in the sample, applying the growth accounting methodology, showed that total factor productivity explains $14 \%$ of average output growth per worker. By total factor productivity they mean: "changes in technology, institutional change, failure of the twin assumption of constant returns to scale and competitive factor markets, and other factors". Barro (1998) points out that technological progress is in fact crucial to the long-term per capita growth that the US economy has been able to sustain for two centuries. Nelson (2000) emphasized that: "In the early 1950s, empirical work made it clear that 'growth of total factor productivity' was accounting for the lion's share of the measured increases in output per worker. Technological advancement was proposed as a major force behind the growth in TFP". Wu, Guo and Marinova (2017) presented new evidence about total factor productivity and economic growth by examining the latest regional and sectoral statistics from China. They found that productivity growth is the main driver of economic growth in all three sectors: agriculture, manufacturing and services. They also found that technological progress is primarily responsible for total factor productivity growth.

Estimation of total factor productivity is important due to its contribution to the long-term income per capita growth. From the computation methodological point of view, beginning from the research of Abramovitz (1956) and Solow (1957), the growth accounting approach has been applied in a significant number of studies.

The sectoral perspective in economic analysis is directly linked to the issue of structural changes. Kratena (2005) stated that shift of resources, output and employment between different sectors accompanying the process of economic growth have been recognized as a possible challenge for adjustment in industrialized economies. Moro (2015) suggested that both the growth rate and the volatility of an economy might be related to its productive structure. 
The article presents the results of growth accounting for seven upper middle-income Balkan countries (Albania, Bosnia and Herzegovina, Bulgaria, North Macedonia, Montenegro, Serbia and Romania), for the period 20002017. While some Balkan countries started their transition process to become market economies at the beginning of the 1990s, others, due to political conflicts and instability, started their transition several years later (notably Bosnia and Herzegovina, Serbia and Montenegro, and North Macedonia). Due to this late transition and their resources being devaluated during the 1990s, these countries have been forced to play catch-up with the other European countries. Of the group of middle-income Balkan countries, Romania and Bulgaria, which started the processes of transition and institutional reform earlier, have made significant progress, especially since their accession to the European Union in 2007. Volatility in output growth ${ }^{1}$ and structural changes were significant in all countries in the sample.

The growth accounting approach was applied to estimate total factor productivity (TFP) in the total economy and at sectoral level for three production sectors, agriculture, industry (including construction) and services. This is the first study presenting estimates of TFP on a sectoral level for a selected group of countries, and also the first study presenting estimates of TFP in the total economy for a selected time period.

The paper is structured into six sections. The key objectives and the aim of the research are presented in the first section. The most relevant literature is reviewed in the second section, followed by the data and methodology description in the third section. In the fourth section the results of the study are presented, followed by a robustness analysis and comparisons with the results from previous studies. The final section presents the conclusion and recommendations for future research.

\section{LITERATURE REVIEW}

Since the studies of Abramovitz (1956) and Solow (1957), total factor productivity accounting has attracted significant attention among scholars. Since then, numerous research studies have been presented, confirming the relevance of TFP for economic growth, and also the sectoral approach in analysis. Nelson (2000), quoting works by Schmookler (1952), Schultz (1953), Fabricant (1954),

\footnotetext{
${ }^{1}$ Average annual GDP growth from 2000 to 2017 in Albania was 4.23\%, followed by Romania $(4.13 \%)$. Average annual GDP growth rates in Bosnia and Herzegovina, Bulgaria, North Macedonia, Montenegro and Serbia, in same period, were 3.3\%, 3.64\%, 2.68\%, $2.96 \%$ and $3.02 \%$, respectively.
} 
Kendrick (1956) and Abramovitz (1956), concluded that the growth output experienced in the United States after World War II has been significantly greater than reasonably can be ascribed to input growth. "Technological advances, the changing composition of the work force, investment in human capital, reallocation of resources from lower to higher productivity activities, economies of scale, all were recognized as parts of the explanation" (Nelson, 2000). On the differences in sectoral productivity, the same author further concluded that "low income countries tend to differ from high income ones in the kinds of economic activities in which they can have comparative advantage, and in internal demand patterns, and these differences profoundly shape the nature of technical innovation that is relevant". He also pointed out the importance of innovation, as being important for providing productivity growth.

Margaritis et al. (2005) showed that labour productivity accounted for roughly half of the growth in per capita GDP in OECD countries over the 1980s and 1990s, with the other half primarily accounted for by increases in labour utilization (changes in demographics, unemployment and labour force participation rates).

Morro (2015) studied the impact of the sectoral composition of GDP on cross-country differences in GDP's growth and volatility, and concluded that an increase in the share of services in GDP reduces both aggregate total factor productivity (TFP) growth and volatility, thus reducing GDP growth and volatility. Foster-McGregor and Verspagen (2017) presented a study on decomposing total factor productivity growth in manufacturing and services, with a sample of 40 countries in the period 1995-2009. Their research showed that "TFP growth in manufacturing tended to outpace that in services in most economies". They found that some exceptions exist, particularly in Asian countries, suggesting that "productivity growth in services need not always be lower than that in manufacturing". Holtgrewe (2015), quoting Baumol (1967) and Scharpf (1986), pointed out what they famously argued that in labourintensive and interactive services, labour productivity cannot be easily increased - a service, which is consumed as it is being produced, takes as long as it needs and involves both the customer's and the worker's time. Therefore, the industrial mechanism of productivity increases do not apply in the service sector.

The most recent study on the growth of total factor productivity in CEE was presented by Levenko, Kaspar and Karsten (2019), on growth accounting for 11 countries from Central and Eastern Europe for the period 1996-2016, in which Bulgaria and Romania were included. Their study showed that for the full sample, average GDP growth was generally higher in the CEE countries than in the reference group of the EU 15 countries from Western Europe; on average TFP growth accounted for one-third of GDP growth, while capital 
deepening accounted for approximately half. Foster-McGregor and Verspagen (2017) presented a study on decomposing TFP growth in manufacturing and services, but their sample of 40 countries included only Bulgaria and Romania from the Balkans, and covered the period 1995-2009. Cungu and Swinnen (2003) measured multifactor agricultural productivity for 23 transition economies in Central and Eastern Europe and the former Soviet Union, from 1992 to 1999, but from the Balkans only Albania, Romania and Bulgaria were included. Their study shows that over the 1992-1999 period, TFP increased consistently in the Balkan countries included in the sample. Swinnen, Van Herck and Vranken (2012) also presented TFP in agriculture in three Balkan countries (Albania, Bulgaria and Romania), for the period 1989-2001. Murgasova et al. (2015) estimated TFP in Western Balkan countries for the period 2001-2008, showing that gains in TFP and capital accumulation were major drivers of growth. Levenko, Kaspar and Karsten (2019) listed several studies on TFP computation for other countries than in the Balkans, such as: Arratibel et al. (2007), Dombi (2013), Vanags and Bems (2005).

\section{DATA AND METHODOLOGY}

\subsection{Data}

The source of all data used in the research was the World Development Indicators database ${ }^{2}$. The rationale behind this was the availability of data for all countries in the sample and consistency in the methodology for the entire period. An international database as the source, instead of national sources, was particularly important as in the non-EU countries from the sample, the statistical systems reforms are still ongoing (Albania, Bosnia and Herzegovina, North Macedonia, Montenegro and Serbia), so the international verification of quality of data is important. Data for Bulgaria and Romania were available at Eurostat database for all those years, and for several years also for other countries in the sample, but not for the total period. The following indicators were used: Gross Domestic Product in constant 2010 USD, value added in agriculture $^{3}$ (constant 2010 USD), value added in industry, including

\footnotetext{
${ }^{2}$ Extracted in April 12, 2019, http://datatopics.worldbank.org/world-development-indicators/

3 Agriculture corresponds to ISIC divisions 1-5 and includes forestry, hunting, and fishing, as well as cultivation of crops and livestock production. Value added is the net output of a sector after adding up all outputs and subtracting intermediate inputs. It is calculated without making deductions for depreciation of fabricated assets or depletion and degradation of natural resources. The origin of value added is determined by the International Standard Industrial Classification (ISIC), revision 3 or 4. (www.worldbank.org)
} 
construction $^{4}$ (constant 2010 USD), value added in services ${ }^{5}$ (constant 2010 USD), gross fixed capital formation (constant 2010 USD) ${ }^{6}$, unemployment rate, total employment ${ }^{7}$, employment in agriculture ( $\%$ of total employment), employment in industry ( $\%$ of total employment), employment in services ( $\%$ of total employment). Two indicators used in this research were estimated: the capital stock at total and sectoral level, and the gross fixed capital formation in agriculture, industry and services, applying the methodology explained in the next section of the paper.

\subsection{Methodology}

TFP growth was estimated applying the growth accounting approach, selected due to its many advantages. "The growth accounting approach provides a filing system that is complete, in the sense that all phenomena that affect economic growth must do so through input factor quantities, relative factor intensities or total factor productivity growth, either individually or in combination. Second, the results of the growth accounting exercise may point to areas where parametric studies are likely to be fruitful" (Norsworthy, 2005).

The starting point is the general specification of aggregate production function, as presented in Levenko, Kaspar and Karsten (2019):

$$
Y_{t}=A_{t} F_{t}\left(h_{t} K_{t}, L_{t}\right)
$$

The variable $Y_{t}$ is output or value added in period $t, K_{t}$ is the economywide capital stock available at the beginning of period $t$, while $h_{t} \in(0,1)$ is the

${ }^{4}$ Industry corresponds to ISIC divisions 10-45 and includes manufacturing (ISIC divisions 15-37). It comprises value added in mining, manufacturing (also reported as a separate subgroup), construction, electricity, water, and gas. Value added is the net output of a sector after adding up all outputs and subtracting intermediate inputs. It is calculated without making deductions for the depreciation of fabricated assets or depletion and degradation of natural resources. The origin of value added is determined by the International Standard Industrial Classification (ISIC), revision 3 or 4. (www.worldbank.org)

5 Services correspond to ISIC divisions 50-99 and include value added in wholesale and retail trade (including hotels and restaurants), transport, and government, financial, professional, and personal services such as education, health care, and real estate. (www.worldbank.org)

6 For Bosnia and Herzegovina, as data were not available, the study estimated GFCF as $G F C F_{\text {constant } 2010 \$, t}=G D P_{\text {constant } 2010 \$, t} G F C F_{\% \text { in } G D P, t}$, as $G D P_{\text {constant } 2010 \$, t}$ and $G C F_{\% \text { in } G D P, t}$ were available in the WDI database. According to the WDI data base, Gross Capital Formation and Gross Fixed Capital Formation were presented as identical in all years.

7 Total employment was computed using WDI data on Total labour force and unemployment rate, as $E_{t}=T L F_{t}\left(1-u_{t}\right)$, where $T L F_{t}$ is total labor force in period t, and $u_{t}$ unemployment rate in period $\mathrm{t}$. 
rate of capital utilization in period $t$, so $h_{t} K_{t}$ is the capital actually utilized for the production of $Y_{t} ; L_{t}$ is employment and $A_{t}$ is a factor scaling aggregator, typically known as total factor productivity (TFP).

As in Levenko, Kaspar and Karsten (2019), if production function is time differenced and perfect competition and constant returns to scale are assumed, the growth rate of output is equal to:

$$
\frac{\Delta Y_{t}}{Y_{t-1}} \approx\left(1-\alpha_{t}^{k}\right) \frac{\Delta L_{t}}{L_{t-1}}+\alpha_{t}^{k} \frac{\Delta K_{t}}{K_{t-1}}+\alpha_{t}^{k} \frac{\Delta h_{t}}{h_{t-1}}+\frac{\Delta A_{t}}{A_{t-1}}
$$

The operator $\Delta$ denotes the first difference, and $\alpha_{t}^{k}$ is the elasticity of output to capital utilized in period $t$. As Levenko, Kaspar and Karsten (2019) stated, equation (2) decomposes output growth into components stemming from growth in employment, growth in available capital, growth in capital utilization and TFP growth.

On a sectoral level, the specification of aggregate production function is:

$$
Y_{t, i}=A_{t, i} F_{t, i}\left(h_{t, i} K_{t, i}, L_{t, i}\right)
$$

The variable $Y_{t, i}$ is value added (output) in period $t$ in sector $i(i=1,2,3$, where 1 denotes agriculture, 2 - industry, 3 - services), $K_{t, i}$ is the economywide capital stock available at the beginning of period $t$ in sector $i$, while $h_{t, i} \in(0,1)$ is the rate of capital utilization in period $t$ so $h_{t} K_{t, i}$ is the capital actually utilized for the production of $Y_{t, i} ; L_{t, i}$ is employment in sector $i$ and $A_{t, i}$ is total factor productivity (TFP) in sector $i$.

The growth rate of output is equal to:

$$
\frac{\Delta Y_{t, i}}{Y_{t-1, i}} \approx\left(1-\alpha_{t, i}^{k}\right) \frac{\Delta L_{t, i}}{L_{t-1, i}}+\alpha_{t, i}^{k} \frac{\Delta K_{t, i}}{K_{t-1, i}}+\alpha_{t, i}^{k} \frac{\Delta h_{t, i}}{h_{t-1, i}}+\frac{\Delta A_{t, i}}{A_{t-1, i}}
$$

The data for output and employment are available, but the data on available stock capital and capital utilization must be computed. Levenko, Kaspar and Karsten (2019) also computed data on elasticity of output to capital, but due to data restriction, the methodology they applied was not applicable in this research, so it was decided to use constant estimates for capital elasticity, equal to 0.33 , suggested as typical value by Romer (2001), on total economy and sectoral level, assuming that:

$$
\alpha_{t, i}^{k}=\alpha_{t}^{k}
$$




\subsubsection{The capital stock}

The data on the capital stock for countries in the sample were not available, so computation was necessary. The author used the perpetual inventory method (PIM), as presented by Berlemann and Wesselhoft (2014). Net capital stock $K_{t}$ at the beginning of period $t$ can be written as a function of the net capital stock $K_{t-1}$ at the beginning of the previous period $t$-1, gross investment in the previous period $I_{t-1}$ and consumption of fixed capital $D_{t-1}$ :

$$
K_{t}=K_{t-1}+I_{t-1}-D_{t-1}
$$

Assuming geometric depreciation at a constant rate $\delta$, the equation can be rewritten as:

$$
K_{t}=(1-\delta) K_{t-1}+I_{t-1}
$$

Repeatedly substituting this equation for the capital stock $K_{t-1}$ at the beginning of period $t-1$, leads to:

$$
K_{t}=\sum_{i=0}^{\infty}(1-\delta)^{i} I_{t-(i+1)}
$$

The capital stock in period $i$ is a weighted sum of the history of capital stock investment. The weighted result from the geometric depreciation function.

In implementing the PIM to construct capital stock data, methodological differences exist, especially in respect of the method of the initial capital stock. Berlemann and Wesselhoft (2014) list three different approaches. In the steady state approach, output grows at the same rate as the capital stock; the disequilibrium approach, in which the growth rate of capital stock can be approximated by the growth rate of investment; and synthetic time series approach, based on the idea of constructing an artificial, historical time series of investment.

Assuming the steady state,

$$
g_{G D P}=g_{K}=\frac{K_{t}-K_{t-1}}{K_{t-1}}=\frac{I_{t}}{K_{t-1}}-\delta
$$

The stock of capital in period $t-1$ is:

$$
K_{t-1}=\frac{I_{t}}{g_{G D P}+\delta} .
$$

The study assumed steady state conditions and used output growth, but as the estimate of the initial capital stock depends crucially on the investment 
and growth rate of output in a single year (Berlemann and Wesselhoft, 2014), to avoid risk of short-term investment shock in initial period, the author used the averages of investment for the first three year period (2000-2002), as suggested by Berlemann and Wesselhoft (2014) and average output (GDP) growth rates for each country for the total period from 2001 to 2017. It was decided to use average GDP growth for the total period to avoid business cycles and shocks to the economy. In estimations on sectoral level, the study used average gross value added growth rates from 2001 to 2017. The anchor year for the stock of capital estimate is 2000. Levenko, Kaspar and Karsten (2019) used output to investment ratio, but later the results from both studies confirmed the accuracy of both approaches. Similarly to Levenko, Kaspar and Karsten (2019), the author assumed that depreciation rate is constant over time and typically also across the countries, and equal to 0.05 for all countries.

The stock of capital for the total economy was estimated using three-year average total gross fixed capital formation (GFCF), the same as sectoral level. Gross fixed capital formation in sector $i$ was computed as:

$$
I_{t, i}=I_{t} E i_{\% E, t}
$$

$I_{t}$ is gross fixed capital formation in the total economy in period $t, E i_{\% E, t}$ is share of employment in sector $i$ in total employment in period $t$. Employment share was selected to provide consistency with the approach to use unemployment rate as the indicator of capital utilization.

The capital stock is then estimated as:

$$
\tilde{K}_{i+1}=K_{t}(1-\delta)+I_{t+1}
$$

for total economy, and

$$
\tilde{K}_{t+1, i}=K_{t, i}(1-\delta)+I_{t+1, i}
$$

for each individual sector, where $I_{t+1}$ is gross fixed capital formation in period $t+1$ for the total economy, and $I_{t+1, i}$ is gross fixed capital formation in sector $i$ in year $t+1$.

\subsubsection{Capital utilization}

In cases of missing data, there are a few options. Levenko, Kaspar and Karsten (2019) used the capacity utilization in manufacturing as a proxy for the utilization of capital in the entire economy, but this study followed Solow's approach and used the change in unemployment rate (Solow, 1957) as the unique indicator in estimation of TFP on total economy and sectoral level. 


\subsubsection{Employment}

The data on employment in total economy and on sectoral level are computed using data on total labour force in the country $\left(L F_{t}\right)$, employment rate for total economy, computed as $e_{t}=1-u_{t}$ and share of employment in each sector in total employment.

$$
L_{t}=L F_{t} e_{t}
$$

for total employment, and

$$
L_{t, i}=L_{t} E i_{\% E, t}
$$

for individual sector, where $u_{t}$ is unemployment rate in period $t, L_{t, i}$ is employment in sector $i$ in period $t$, and $E i_{\% E, t}$ is share of sector $i$ in total employment in period $t$.

\section{RESULTS OF THE BASELINE SCENARIO}

Applying the methodology and assumptions presented in Section 3, the author estimated the baseline series for the capital stock in total economy and on sectoral level, as well as the series for gross fixed capital formation on sectoral level ${ }^{8}$. This section presents the results on decomposition of output growth for total economy, each sector, total time frame (Table 1) and subperiods (2000-2009 and 2010-2017; see Table 2).

Variations among output growth rates, TFP and contributions from capital and labour were observed not only among countries, but also among sectors in each country and time frame. From 2000 to 2017, the largest TFP growth in total economy was observed in Romania, which is the second leading output growth in the sample, with an average output growth rate of $4.13 \%$. The highest average output growth rate was evidenced in Albania, although average TFP growth was lower compared to Bosnia and Herzegovina, Serbia and Romania. This is mainly due to larger capital utilization and growth in employment. The average TFP growth was also high in Serbia (2.08), with an output growth of 3.02. In Montenegro and Macedonia, the countries with the lowest average annual GDP growth in the sample, the average TFP growth rate was negative, while growth of capital and growth in capital utilization were relatively high.

If one compares average TFP growth rates for total economy and at sectoral level, TFP growth in industry is the most correlated with total TFP growth. TFP growth in industry was positive in all countries using averages for the

\footnotetext{
${ }^{8}$ Data available on request.
} 
total period. In agriculture, TFP growth was higher than the total in Albania, Bulgaria, Montenegro, Serbia and Romania, and was the most important factor for value added growth in agriculture. TFP growth was the lowest in the services sector, and even negative in four countries from the sample (Albania, Bulgaria, North Macedonia and Montenegro).

The contribution of capital to growth was very similar in all the countries from the sample, on average between 1-2\% annually for total economy, but above $2 \%$ in most countries in industry, and in Bulgaria and Serbia in services. In agriculture, the contribution of capital was lower than $1 \%$ in most countries (except for Albania and Romania). The contribution of employment was much lower compared to capital, and even negative in Bosnia and Herzegovina, Serbia and Romania. Levenko, Kaspar and Karsten (2019) also found that contribution of employment has a low significance. On sectoral level, employment growth has the largest contribution to growth in services. The contribution of capital utilization was positive in most countries, but most significant in Bulgaria and Montenegro.

Sub-period analysis showed variations in the growth in all the components measured in the baseline scenario. Average output growth was higher in all the countries for 2000-2009 than for 2010-2017. Variations were high in several countries from the sample. In Albania, average output growth was $4.7 \%$ in the earlier, but $1.74 \%$ in the later subperiod. In Bosnia and Herzegovina $4.7 \%$ and $1.74 \%$ respectively, in Bulgaria 5.01\% and $2.10 \%$, in Serbia $4.91 \%$ and $0.89 \%$ and Romania 5.12\% and 3.02\%. In North Macedonia and Montenegro the variations were smaller, $2.97 \%$ and $2.34 \%$ in the first and $3.43 \%$ and $2.44 \%$ in the second subperiod. The lower growth rates in the later period were mostly due to slower growth in industry and services (the only exception was North Macedonia where both industry and services grew faster in the later period, and also Serbia in the industry sector where the growth rate remained almost unchanged, and in Romania also in services also). The total factor productivity growth also varied in all the countries, in some cases even rapidly. In Romania, average TFP growth decreased from $4.63 \%$ in the earlier, to $0.51 \%$ in the later period. In North Macedonia it even shifted to a negative value, from $1.21 \%$ to $-0.87 \%$. Montenegro improved TFP, shifting from negative value $(-1.7 \%)$ to $0.22 \%$, and also Bulgaria, from $-0.83 \%$ to $1.99 \%$.

Output growth in agriculture increased in Bulgaria, Montenegro and Romania from 2010 to 2017, but decreased in all the other countries. TFP growth increased in Bulgaria, but decreased in other countries. Industry had slower growth in the later subperiod in all the countries other than North Macedonia and Serbia. The total factor productivity growth in industry only increased in Bulgaria. Value Added in services grew by a higher rate from 2010 to 2017 in Montenegro and North Macedonia, but at a slower rate in 
Table 1

Decomposition of output growth, total economy and sectoral approach, (2000-2017)

\begin{tabular}{|c|c|c|c|c|c|}
\hline & & & & & \\
\hline & & \multicolumn{4}{|c|}{$2000-2017$} \\
\hline & & Total & Agriculture & $\begin{array}{c}\text { Industry } \\
\text { (incl. construction) }\end{array}$ & Services \\
\hline \multirow{5}{*}{ 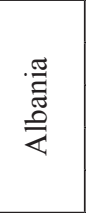 } & GDP/Value Added & 4.23 & 3.15 & 5.09 & -1.62 \\
\hline & Employment & 0.40 & -1.20 & 1.06 & 2.93 \\
\hline & Capital & 1.68 & 1.07 & 2.00 & 0.77 \\
\hline & Utilization & 0.85 & 0.85 & 0.85 & 0.85 \\
\hline & TFP & 1.31 & 2.44 & 1.18 & -6.17 \\
\hline \multirow{5}{*}{ 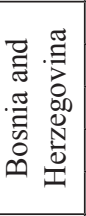 } & GDP/Value Added & 3.30 & 0.85 & 4.74 & 3.35 \\
\hline & Employment & -0.15 & -1.52 & 0.58 & 0.29 \\
\hline & Capital & 1.17 & 0.32 & 1.57 & 1.30 \\
\hline & Utilization & -0.04 & -0.04 & -0.04 & -0.04 \\
\hline & TFP & 2.32 & 2.10 & 2.64 & 1.81 \\
\hline \multirow{5}{*}{ 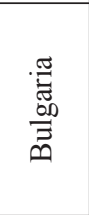 } & GDP/Value Added & 3.64 & -0.29 & 3.69 & 3.62 \\
\hline & Employment & 0.25 & -2.36 & -0.14 & 0.94 \\
\hline & Capital & 1.68 & 0.21 & 1.67 & 1.79 \\
\hline & Utilization & 1.22 & 1.22 & 1.22 & 1.22 \\
\hline & TFP & 0.49 & 0.65 & 0.94 & -0.33 \\
\hline \multirow{5}{*}{ 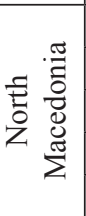 } & GDP/Value Added & 2.68 & 0.31 & 4.28 & 2.74 \\
\hline & Employment & 1.09 & 0.05 & 0.63 & 1.97 \\
\hline & Capital & 1.17 & 0.32 & 1.33 & 1.45 \\
\hline & Utilization & 0.65 & 0.65 & 0.65 & 0.65 \\
\hline & TFP & -0.24 & -0.71 & 1.66 & -1.33 \\
\hline \multirow{5}{*}{ 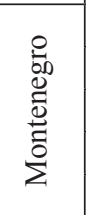 } & GDP/Value Added & 2.96 & 2.24 & 8.49 & -0.30 \\
\hline & Employment & 0.90 & 0.04 & -0.02 & 1.44 \\
\hline & Capital & 1.66 & 0.94 & 2.12 & 1.02 \\
\hline & Utilization & 1.20 & 1.20 & 1.20 & 1.20 \\
\hline & TFP & -0.79 & 0.07 & 5.19 & -3.96 \\
\hline \multirow{5}{*}{ 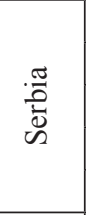 } & GDP/Value Added & 3.02 & 1.03 & 1.70 & 2.84 \\
\hline & Employment & -0.29 & -1.76 & -0.80 & 0.91 \\
\hline & Capital & 1.76 & 0.91 & 1.30 & 2.04 \\
\hline & Utilization & -0.53 & -0.53 & -0.53 & -0.53 \\
\hline & TFP & 2.08 & 2.41 & 1.73 & 0.43 \\
\hline \multirow{5}{*}{ 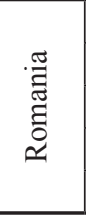 } & GDP/Value Added & 4.13 & 3.97 & 4.37 & 4.46 \\
\hline & Employment & -1.00 & -3.43 & -0.52 & 0.97 \\
\hline & Capital & 1.97 & 1.29 & 2.16 & 2.60 \\
\hline & Utilization & 0.47 & 0.47 & 0.47 & 0.47 \\
\hline & TFP & 2.69 & 5.64 & 2.26 & 0.41 \\
\hline
\end{tabular}

Source: authors' calculation. 
Table 2

Decomposition of output growth, total economy and sectoral approach, (2000-2009, 2010-2017)

\begin{tabular}{|c|c|c|c|c|c|c|c|c|c|}
\hline & & \multicolumn{2}{|c|}{ Total } & \multicolumn{2}{|c|}{ Agriculture } & \multicolumn{2}{|c|}{$\begin{array}{c}\text { Industry } \\
\text { (incl. construction) }\end{array}$} & \multicolumn{2}{|c|}{ Services } \\
\hline & & $\begin{array}{c}2000- \\
2009\end{array}$ & $\begin{array}{l}2010- \\
2017\end{array}$ & $\begin{array}{l}2000- \\
2009\end{array}$ & $\begin{array}{l}2010- \\
2017\end{array}$ & $\begin{array}{c}2000- \\
2009\end{array}$ & $\begin{array}{l}2010- \\
2017\end{array}$ & $\begin{array}{c}2000- \\
2009\end{array}$ & $\begin{array}{c}2010- \\
2017\end{array}$ \\
\hline \multirow{5}{*}{ 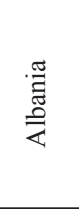 } & GDP/Value Added & 5.79 & 2.48 & 3.27 & 3.03 & 9.00 & 0.68 & 5.95 & -10.13 \\
\hline & Employment & 0.11 & 0.74 & -2.35 & 0.07 & 1.87 & 0.18 & 3.95 & 1.86 \\
\hline & Capital & 2.06 & 1.26 & 1.41 & 0.68 & 2.65 & 1.27 & 0.48 & 1.11 \\
\hline & Utilization & 1.74 & -0.16 & 1.74 & -0.16 & 1.74 & -0.16 & 1.74 & -0.16 \\
\hline & TFP & 1.89 & 0.65 & 2.44 & 2.43 & 2.76 & -0.61 & -0.17 & -12.91 \\
\hline \multirow{5}{*}{ 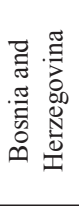 } & GDP/Value Added & 4.70 & 1.74 & 2.31 & -0.79 & 6.82 & 2.40 & 4.79 & 1.74 \\
\hline & Employment & 0.45 & -0.83 & -1.88 & -1.17 & 0.96 & 0.16 & 1.36 & -0.91 \\
\hline & Capital & 1.57 & 0.72 & 0.62 & -0.02 & 2.02 & 1.06 & 1.71 & 0.85 \\
\hline & \begin{tabular}{|l|} 
Utilization \\
\end{tabular} & 0.20 & -0.31 & 0.20 & -0.31 & 0.20 & -0.31 & 0.20 & -0.31 \\
\hline & TFP & 2.48 & 2.15 & 3.34 & 0.69 & 3.66 & 1.49 & 1.54 & 2.10 \\
\hline \multirow{5}{*}{ 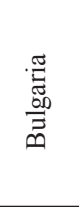 } & GDP/Value Added & 5.01 & 2.10 & -0.63 & 0.09 & 5.62 & 1.52 & 4.77 & 2.33 \\
\hline & Employment & 0.99 & -0.59 & -3.13 & -1.56 & 1.57 & -2.08 & 1.49 & 0.34 \\
\hline & Capital & 2.28 & 0.99 & 0.44 & -0.06 & 2.45 & 0.78 & 2.31 & 1.21 \\
\hline & Utilization & 2.58 & -0.30 & 2.58 & -0.30 & 2.58 & -0.30 & 2.58 & -0.30 \\
\hline & TFP & -0.83 & 1.99 & -0.55 & 1.99 & -0.96 & 3.08 & -1.59 & 1.08 \\
\hline \multirow{5}{*}{ 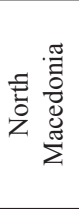 } & GDP/Value Added & 2.97 & 2.34 & 3.70 & -3.50 & 3.39 & 5.28 & 2.65 & 2.85 \\
\hline & Employment & 0.91 & 1.31 & 0.13 & -0.04 & -0.06 & 1.43 & 2.20 & 1.76 \\
\hline & Capital & 0.91 & 1.46 & 0.05 & 0.62 & 1.19 & 1.49 & 1.15 & 1.79 \\
\hline & Utilization & -0.05 & 1.45 & -0.05 & 1.45 & -0.05 & 1.45 & -0.05 & 1.45 \\
\hline & TFP & 1.21 & -1.87 & 3.57 & -5.52 & 2.31 & 0.93 & -0.62 & -2.13 \\
\hline \multirow{5}{*}{ 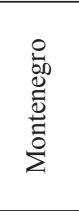 } & GDP/Value Added & 3.43 & 2.44 & 1.66 & 2.91 & 12.84 & 3.59 & -2.95 & 2.69 \\
\hline & Employment & 1.47 & 0.28 & -2.60 & 3.01 & 0.38 & -0.47 & 2.46 & 0.33 \\
\hline & Capital & 2.01 & 1.26 & 1.23 & 0.61 & 2.90 & 1.23 & 1.06 & 0.98 \\
\hline & Utilization & 1.67 & 0.67 & 1.67 & 0.67 & 1.67 & 0.67 & 1.67 & 0.67 \\
\hline & TFP & -1.70 & 0.22 & 1.33 & -1.35 & 7.89 & 2.14 & -8.11 & 0.71 \\
\hline \multirow{5}{*}{$\frac{\pi}{0}$} & GDP/Value Added & 4.91 & 0.89 & 1.52 & 0.48 & 1.69 & 1.70 & 4.54 & 0.93 \\
\hline & Employment & -0.78 & 0.24 & -1.95 & -1.59 & -1.45 & -0.10 & 0.55 & 1.33 \\
\hline & Capital & 2.22 & 1.24 & 1.19 & 0.59 & 1.70 & 0.86 & 2.46 & 1.57 \\
\hline & \begin{tabular}{|l} 
Utilization \\
\end{tabular} & -1.25 & 0.28 & -1.25 & 0.28 & -1.25 & 0.28 & -1.25 & 0.28 \\
\hline & TFP & 4.70 & -0.86 & 3.51 & 1.18 & 2.67 & 0.67 & 2.79 & -2.23 \\
\hline \multirow{5}{*}{ 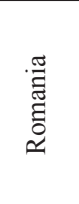 } & GDP/Value Added & 5.12 & 3.02 & 2.99 & 5.08 & 7.23 & 1.14 & 4.51 & 4.39 \\
\hline & Employment & -1.75 & -0.19 & -4.73 & -2.05 & -0.62 & -0.42 & 0.81 & 1.18 \\
\hline & Capital & 2.43 & 1.45 & 1.67 & 0.87 & 2.82 & 1.41 & 3.13 & 2.01 \\
\hline & \begin{tabular}{|l|} 
Utilization \\
\end{tabular} & -0.21 & 1.24 & -0.21 & 1.24 & -0.21 & 1.24 & -0.21 & 1.24 \\
\hline & TFP & 4.63 & 0.51 & 6.20 & 5.00 & 5.24 & -1.10 & 0.79 & -0.02 \\
\hline
\end{tabular}

Source: authors' calculation. 
other countries. In Albania, average VA growth in services was even negative from 2010 to 2017. TFP growth was higher in the later subperiod in Bosnia and Herzegovina, Bulgaria and Montenegro.

The contribution of capital to growth declined in the later period in almost all the countries and sectors. Exceptions were North Macedonia (total economy and all sectors), and the services sector in Albania.

The contribution of employment, except in Serbia and Romania, where it increased in total economy and all sectors, declined in most of the other countries and almost in all the sectors (except for total economy and agriculture in Albania, total economy and industry in North Macedonia, agriculture in Bulgaria and Montenegro). Capital utilization was higher from 2010 to 2017, compared to the previous subperiod in North Macedonia and Serbia, but lower in all other countries.

\section{ROBUSTNESS ANALYSIS AND COMPARISON WITH RESULTS FROM OTHER RESEARCHES}

Measuring TFP applying the growth accounting approach has its difficulties. A fairly innocuous deference in assumptions can lead to very different estimates of TFP growth (PREM notes, 2000), this is why it is important to show sensitivity of the results by changing assumptions.

\subsection{Changing assumptions}

This section shows the sensitivity of the results by changing the calculation method for the capital stock. As explained earlier, in the baseline scenario, the author used average output growth rate from 2000 to 2017. If the method is

Table 3

Decomposition of output growth, total economy, (2001-2017), using GFCF growth rate

\begin{tabular}{|c|c|c|c|c|c|}
\hline & \multicolumn{5}{|c|}{$2000-2017$} \\
\hline & GDP & Employment & Capital & Utilization & TFP \\
\hline Albania & 4.23 & 0.40 & 2.00 & 0.85 & 0.99 \\
\hline Bosnia and Herzegovina & 3.30 & -0.15 & 1.16 & -0.04 & 2.34 \\
\hline Bulgaria & 3.64 & 0.25 & 2.02 & 1.22 & 0.15 \\
\hline North Macedonia & 2.68 & 1.09 & 1.69 & 0.65 & -0.75 \\
\hline Montenegro & 2.96 & 0.90 & 2.70 & 1.20 & -1.84 \\
\hline Serbia & 3.02 & -0.29 & 2.47 & -0.53 & 1.37 \\
\hline Romania & 4.13 & -1.00 & 2.52 & 0.47 & 2.14 \\
\hline
\end{tabular}

Source: authors' calculation. 
changed, using average gross fixed capital formation growth rate for same time frame (Table 3), the contribution of TFP growth is smaller in all the countries except for Bosnia and Herzegovina.

Table 4

Decomposition of output growth, total economy, (2001-2017), using depreciation rate of 3\%

\begin{tabular}{l|c|c|c|c|c}
\cline { 2 - 6 } & \multicolumn{5}{c}{ 2000-2017 } \\
\cline { 2 - 6 } & GDP & Employment & Capital & Utilization & TFP \\
\hline Albania & 4.23 & 0.40 & 1.28 & 0.85 & 1.71 \\
\hline Bosnia and Herzegovina & 3.30 & -0.15 & 0.76 & -0.04 & 2.74 \\
\hline Bulgaria & 3.64 & 0.25 & 1.25 & 1.22 & 0.92 \\
\hline North Macedonia & 2.68 & 1.09 & 0.73 & 0.65 & 0.21 \\
\hline Montenegro & 2.96 & 0.90 & 1.19 & 1.20 & -0.32 \\
\hline Serbia & 3.02 & -0.29 & 1.29 & -0.53 & 2.56 \\
\hline Romania & 4.13 & -1.00 & 1.55 & 0.47 & 3.11 \\
\hline
\end{tabular}

Source: authors' calculation.

The results are also sensitive to the depreciation rate. If, instead of 0.05 , one applies a depreciation rate of 0.03 , the contribution of TFP growth is larger in the all countries, while the capital stock growth is smaller (Table 4).

\subsection{Comparisons of results with other research}

Although earlier research on TFP measured applying growth accounting method does not cover the same sample and time frame, there are some overlaps which make a comparison possible. The study by Levenko, Kaspar and Karsten (2019) is the most comparable in terms of time frame as well asthe methodology and the sample (two countries from both samples overlaps).

A comparison of the TFP growth in Bulgaria and Romania from both studiesshows that both results are similar if usingthe averages for the total periods. Average TFP growth rate from 1996 to 2016 in Bulgaria is 0.67 in Levenko, Kaspar and Karsten (2019) while from 2001 to 2017 this was 0.49 in the baseline scenario of this research. Splittingthe time frame, the author observed similar results from the research from 2000 to 2009 and that by Levenko, Kaspar and Karsten (2019) from 2002-2007 and 2008-2009 calculated for Romania, while for Bulgaria there are some differences, namely -0.83 in this research and 0.95/0.15 in Levenko, Kaspar and Karsten (2019). 
Table 5

Comparisons of the results with those presented in the study by Levenko, Kaspar and Karsten (2019)

\begin{tabular}{l|c|c|c|c}
\hline Study & $\begin{array}{c}\text { Bacovic } \\
(2019)\end{array}$ & $\begin{array}{c}\text { Levenko, Kaspar } \\
\text { and Karsten } \\
(2019)\end{array}$ & $\begin{array}{c}\text { Bacovic } \\
(2019)\end{array}$ & $\begin{array}{c}\text { Levenko, Kaspar } \\
\text { and Karsten } \\
(2019)\end{array}$ \\
\hline Time frame & $2000-2017$ & $1996-2016$ & $2000-2009$ & $2002-2007 / 2008-2009$ \\
\hline Bulgaria & 0.49 & 0.67 & -0.83 & $0.95 / 0.15$ \\
\hline Romania & 2.69 & 2.45 & 4.63 & $5.91 /-0.13$ \\
\hline
\end{tabular}

Sources: authors' calculation; Levenko, Kaspar and Karsten (2019).

\section{CONCLUSION}

In this study, the author decomposed GDP growth and value added on sectoral level (agriculture, industry and services), in seven upper-middle income Balkan countries, from 2000 to 2017, and two subperiods, from 2000 to 2009 and from 2010 to 2017, using the growth accounting approach. As some data were unavailable, computation of two variables was necessary, the capital stock at all levels, and gross fixed capital formation at sectoral level. The study used PIM with the steady state approach, but the robustness check showed that a variation between the results, if one applies the disequilibrium approach, are towards a lower contribution of TFP but higher from capital, but not sufficiently significant to change the approach. The comparisons of the results from this research with similar studies also showed low level of variations.

The research confirmed the importance of growth measurement and its decomposition, as well as of the sectoral approach, as the variation between TFP and other components of output growth in total economy and at sectoral level are significant. The sectoral approach provides a more detailed insight into overall structural changes in the economy. The author's analysis showed that TFP growth in industry is most correlated with total TFP growth. In agriculture, TFP growth was higher than the total growth in Albania, Bulgaria, Montenegro, Serbia and Romania, and was the most important factor for value added growth in agriculture. TFP growth was the lowest in the services sector, and even negative in four countries from the sample (Albania, Bulgaria, North Macedonia and Montenegro). The sub-period analysis is also important, showing significant variations between the two periods, and also among the sectors and factors contributing in both time frames. Average output growth 
was higher in all countries from 2000 to 2009 than from 2010 to 2017. TFP growth also varied in all the countries, in some cases even rapidly, while in some countries from the sample it decreased, in some it increased from 2010. The contributions of capital and labour also decreased in several countries.

The research showed volatility in all the elements, output growth and decomposed contribution of inputs and TFP. Structural changes were evidenced in all the countries, with a declining share of agriculture, a moderate growth in industry (except in Montenegro), and an overall growth in services. Total factor productivity growth, other than being volatile, was significantly different in various sectors, the lowest in services. The contribution of capital is significant, but less than that of employment.

The results of the study may be used in defining national policies priorities, as the relevance of TFP growth for long-term growth is unquestionable, but there are some variations among the sectors in terms of growth in TFP.

The overall growth in the services sector, observed in all the countries, should be analysed seriously. While the growth of the services sector and its significance for overall value added growth and employment is evident, its contribution to long-term growth, through TFP growth, is still an issue in many debates. As Morro (2015) concluded, an increase in the share of services in GDP reduces both aggregate total factor productivity (TFP) growth and volatility, thus reducing GDP growth and volatility. This should encourage economic policy makers to emphasize industry development more. National policies should prioritize measures that support the development of those components relevant for TFP growth. Based on an extensive literature review, Kim and Loayza (2017) concluded that the variation of TFP across countries for the last three decades is mostly explained by the physical infrastructure, followed by education, market efficiency, innovation and institutional infrastructure.

The main contribution of this study to the literature is the decomposition of output growth computation on sectoral level, and also the presented methodology for data computations on sectoral level, as due to missing data, two key variables had to be computed: the capital stock and gross fixed capital formation.

The results of this study may be an incentive for further research, to a further investigation of determinants of changes in output, TFP growth and structural changes, empirically evidenced in this study. 


\section{REFERENCES}

Abramovitz, M., Resource and Output Trends in the United States since 1870. NBER, 1956.

Arratibel, 0., Heinz, F., Martin, R., Przybyla, M., Rawdanowicz, L., Serafini, R., Zumer, T., Determinants of growth in the Central and Eastern European EU member states A production function approach. European Central Bank, ECB Occasional Paper, No. 61, Frankfurt 2007.

Baier, S., Dwyer, G., Tamura, R., How important are capital and total factor productivity for economic growth?, "Economic Inquiry”, No. 44 (1), pp. 23-49, 2006.

Barro, J. R., Macroeconomics, 5th edition. The MIT Press, Cambridge, Massachusetts, London, England, 1998.

Berlemann, M., Wesselhoft, J.-E., Estimating Aggregate Capital Stocks Using the Perpetual Inventory Method, "Review of Economics", No. 65, pp. 1-34, 2014.

Comin, D., Total factor productivity [in:] Durlauf, S., Blume, L., Economic Growth, pp. 260-263. The New Palgrave Economics Collection, Palgrave Macmillan, London 2010.

Cungu, A., Swinnen, F. J., Transition and Total Factor Productivity in Agriculture 1992-1999. Leuven, Belgium: Research Group on Food Policy, Transition \& Development (PRGLeuven) \& LICOSCentre for TRansition Economics, K. U. Leuven 2003.

Dombi, A., Economic Growth and Development in Central and Eastern Europe after the Transformation, "Public Finance Quarterly", No. 58 (4), pp. 452-468, 2013.

Foster-McGregor, N., Verspagen, B., Decomposing Total Factor Productivity Growth in Manufacturing and Services, "Asian Development Review”, No. 34(1), pp. 88-115, 2017.

Holtgrewe, U., Services Research along the Service Process: An overview study to support UNI Europa's. Forba, Vienna 2015.

Kim, Y., Loyaza, N., Productivity and its Determinants: Innovation, Education, Efficiency, Infrastructure, and Institutions. Retrieved from http://pubdocs.worldbank.org/en/ 378031511165998244/Productivity-and-its-determinants-25-October-2017.pdf, 2017.

Kratena, K., Sectoral Economy: Do sectors Really Matter? "Estudios de Economia Aplicada", No. 23(2), pp. 289-298, 2005.

Levenko, N., Kaspar, O., Karsten, S., Total factor productivity growth in Central and Eastern Europe before, during and after the global financial crisis. "Post-Communist Economies", No. 31(2), pp. 137-160, 2019.

Moro, A., Structural Change, Growth and Volatility, “American Economic Journal: Macroeconomics", No. 7(3), pp. 259-294, 2015.

Murgasova, S., Ilahi, N., Miniane, J., Scott, A., Vladkova-Hollar, I., \& IMF staff, The Western Balkan Countries, 15 years of Economic Transition. International Monetary Fund, Washington D.C. 2015.

Nelson, R. R., The Sources of Economic Growth. Harvard University Press, Cambridge, Massachusetts/London, England, 2000.

Norsworthy, J., Growth Accounting and Productivity Measurement, "Review of Income and Wealth", No. 30(3), pp. 309-329, 2005.

Prem notes. Measuring growth in total factor productivity. The World Bank, Washington, D.C., 2000. 
Romer, D., Advanced Macroeconomics. McGrawHill, USA 2001.

Solow, M. R., Technical Change and the Aggregate Production Function, "The Review of Economics and Statistics", No. 39(3), pp. 312-320, 1957.

Swinnen, J., Van Herck, K., Vranken, L., Agricultural Productivity Paths in Central and Eastern European Countries and the Former Soviet Union: the Role of Reforms, Initial Conditions and Induced Technological Change [in:] Fuglie, K., Wang, S., Ball, V. E., Productivity Growth in Agriculture: An International Perspective. CABI 2012.

Vanags, A., Bems, R., Growth acceleration in the Baltic States:. Baltic International Centre for Economic Policy Studies, 2005.

Wu, Y., Guo, X., Marinova, D., Productivity, Innovation and China's Economic Growth [in:] Song, L., Garnaut, R., Fang, C. Johnston, L., China's New Sources of Economic Growth. ANU Press, 2017.

Received: May 2019, revised: September 2020 